\title{
MONITORING OF PRASEODYMIUM(III) IONS IN AQUEOUS SOLUTIONS, SOIL AND SEDIMENT SAMPLES BY A PVC MEMBRANE SENSOR BASED ON A FURAN-TRIAZOLE DERIVATIVE
}

\author{
Mohammad Reza Pourjavid* \\ Nuclear Science \& Technology Research Institute, P.O. Box 11365-8486, Tehran / Department of Medicinal Chemistry, \\ Pharmaceutical Sciences Branch, Islamic Azad University, Tehran, Iran \\ Mohammad Rezaee and Majid Haji Hosseini \\ Nuclear Science \& Technology Research Institute, P.O. Box 11365-8486, Tehran, Iran \\ Taherehsadat Razavi \\ Instrumental Analysis Department, Research Institute of Petroleum Industry, P.O. Box 14665-137, Tehran, Iran
}

Recebido em 26/2/12; aceito em 7/7/12; publicado na web em 21/9/12

\begin{abstract}
A furan-triazole derivative has been explored as an ionophore for preparation of a highly selective $\operatorname{Pr}(\mathrm{III}) \operatorname{membrane}$ sensor. The proposed sensor exhibits a Nernstian response for $\operatorname{Pr}(\mathrm{III})$ activity over a wide concentration range with a detection limit of $5.2 \times 10^{-8}$ M. Its response is independent of $\mathrm{pH}$ of the solution in the range 3.0-8.8 and offers the advantages of fast response time. To investigate the analytical applicability of the sensor, it was applied successfully as an indicator electrode in potentiometric titration of $\operatorname{Pr}(\mathrm{III})$ solution and also in the direct and indirect determination of trace $\operatorname{Pr}(\mathrm{III})$ ions in some samples.
\end{abstract}

Keywords: membrane sensor; $\operatorname{Pr}(\mathrm{III})$ selective; furan-triazole derivative.

\section{INTRODUCTION}

Praseodymium is soft silvery metal used as an alloying agent with magnesium for the production of high strength metal alloys used in aircraft engines. It forms the core of carbon arc lights for the motion picture industry and didymium glass to make certain types of welders and glass blower's goggles (with a yellow color). Praseodymium also has applications in household devices such as color televisions, fluorescent lamps, energy saving lamps and glasses. It is added to fiber optic cables as a doping agent where it acts as a signal amplifier. The toxicity of praseodymium is low to moderate. This metal is most dangerous in the working environment, due to the fact that damps and gases can be inhaled with air. This can cause lung embolisms, especially following long-term exposure. Praseodymium can be a threat to the liver when it accumulates in the human body. ${ }^{1,2}$ Thus, the determination of praseodymium in different samples is of special interest.

Ion selective electrodes are used widely in the analysis of a wide variety of ions ${ }^{3}$ because they have some outstanding advantages including simple design and operation, wide linear dynamic range, relatively fast response and rational selectivity in comparison with new electrochemical methods. ${ }^{4-6} \mathrm{~A}$ very interesting development of potentiometric sensors is the construction of an electrode that responds selectively to lanthanide ions. Recently, we and other groups reported some sensors for lanthanide ions. ${ }^{7-9}$ To the best of our knowledge, the first $\operatorname{Pr}(\mathrm{III})$ ion selective membrane sensor was prepared by Ganjali et $a l$. with the use of N'-(pyridin-2-ylmethylene)benzohydrazide ${ }^{10}$ and subsequent reports were published by them and other groups. ${ }^{11}$ This study describes another ion selective sensor for $\operatorname{Pr}(\mathrm{III})$ potentiometric determination based on 3-nitro-4-amino-5-naphtho[2,1-b]furan-2-yl-4H-1,2,4-triazole-3-thiol (NAFT), as a novel neutral ionophore (Figure 1). Three notable benefits demonstrated by this sensor are fast response time, low detection limit and also great selectivity.

The exclusive donating role of nitrogen and sulfur atoms through their coordination with transition metal ions is known. In aqueous solution, little reaction occurs between these ligands and either alkali

*e-mail: pourjavid@gmail.com

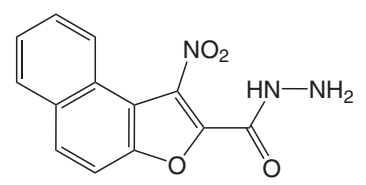

(I)

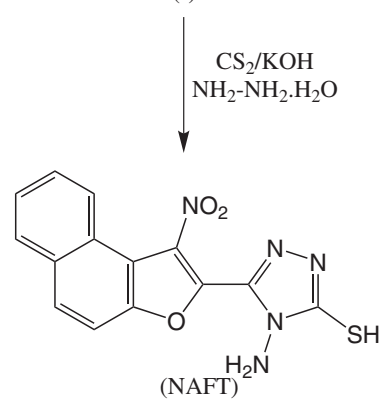

Figure 1. The schematic diagram of procedure of NAFT preparation from 3-nitronaphtho[2,1-b]furan-2-carbonhydrazide

or alkaline earth metal ions, but the ionophores having nitrogen and sulfur atoms as donor atoms are known to form highly stable complexes with transition metal ions. ${ }^{4,5,7,9}$ The resulting 1:1 complexes have been frequently used as catalysts in a diverse range of processes, e.g. oxygen and atom transfer. ${ }^{12}$ Due to the radii of lanthanum ions (with the range of 1.02-0.80 $\AA$ from $\mathrm{Ce}^{3+}$ to $\mathrm{Lu}^{3+}$, respectively), these elements have different properties such as charge densities, size and hydration energy (with the range of $3370-3760 \mathrm{~kJ} / \mathrm{mol}$ from $\mathrm{Ce}^{3+}$ to $\mathrm{Lu}^{3+}$, respectively). ${ }^{13}$ By using a suitable ionophore having a semi-cavity and relatively high flexibility, it is possible to construct a highly selective lanthanide ion sensor. Thus, a conductivity study of complexation in the acetonitrile solution was carried out as a primary test.

\section{EXPERIMENTAL}

Apparatus and reagents

A corning ion analyzer $250 \mathrm{pH} / \mathrm{mV}$ meters was used for the 
potential measurements at $25.0 \pm 0.1{ }^{\circ} \mathrm{C}$. The emf observations were made relative to a double-junction saturated calomel electrode (SCE, Philips), with its chamber filled with an ammonium nitrate solution. Reagent grade sodium tetra phenyl borate (NaTPB), dibutyl phthalate (DBP), nitrobenzene (NB), benzyl acetate (BA), o-nitrophenyloctyl ether (o-NPOE), acetophenone (AP), tetrahydrofuran (THF), perchloric acid, hydrofluoric acid and high relative molecular weight PVC (all from Fluka) were used as received. The ionophore (NAFT) was prepared from 3-nitronaphtho[2,1-b]furan-2-carbonhydrazide as described elsewhere. ${ }^{14}$ The schematic diagram of the procedure is shown in Figure 1. All reagents were used without modification. The nitrate salts of all the cations employed were of the highest available purity and were $\mathrm{P}_{2} \mathrm{O}_{5}$-vacuum dried. Triply distilled deionized water was used in the experiments.

\section{Electrode and sample preparation}

The general procedure to prepare the PVC membrane was to thoroughly mix $30 \mathrm{mg}$ of powdered PVC, $59 \mathrm{mg}$ of plasticizer o-NPOE, $3 \mathrm{mg}$ of additive NaTPB, and $8 \mathrm{mg}$ of NAFT in a glass dish $2 \mathrm{~cm}$ in diameter. In the first experiment, $30 \mathrm{mg}$ PVC, $61 \mathrm{mg}$ DBP, $7 \mathrm{mg}$ NAFT and $2 \mathrm{mg}$ NaTPB were used for membrane fabrication. The mixture was then completely dissolved in $5 \mathrm{~mL}$ of THF. The solvent was evaporated slowly until an oily concentrated mixture was obtained. A Pyrex tube (3-5 mm o.d.) was dipped into the mixture for about $10 \mathrm{~s}$, to allow a nontransparent, $0.3 \mathrm{~mm}$-thick membrane to form. ${ }^{15}$ The tube was then withdrawn from the mixture and kept at room temperature for $24 \mathrm{~h}$. The tube was filled with internal filling solution $\left(1.0 \times 10^{-4} \mathrm{M} \operatorname{Pr}\left(\mathrm{NO}_{3}\right)_{3}\right)$. The electrode was finally conditioned for $18 \mathrm{~h}$ in a $1.0 \times 10^{-4} \mathrm{M}$ solution of praseodymium(III) nitrate.

In the titration test, a $20 \mathrm{~mL}\left(1.0 \times 10^{-4} \mathrm{M}\right)$ solution of $\operatorname{Pr}(\mathrm{III})$ was titrated with a $1.0 \times 10^{-2} \mathrm{M}$ solution of EDTA $(\mathrm{pH}=10.0)$. For $\operatorname{Pr}(\mathrm{III})$ ions determination in solid and sediment samples, a sample (1 g) was weighed into a PTFE beaker. Subsequently, $5 \mathrm{~mL}$ of $70 \% \mathrm{HClO}_{4}$ and $10 \mathrm{~mL}$ of $48 \% \mathrm{HF}$ were added. The sample was heated in a sand bath to incipient dryness. The acid attack with $\mathrm{HClO}_{4}$ and $\mathrm{HF}(1+2)$ was repeated three times to complete the digestion of the silicate matrix. Afterwards, the samples were transferred into flasks and diluted with 5 $\mathrm{mL}$ of $\mathrm{NaOH} 5 \%$ and distilled water to $50 \mathrm{~mL}\left(\mathrm{pH}\right.$ ). ${ }^{16}$ The potential of these solutions was then measured by employing the developed $\operatorname{Pr}(\mathrm{III})$ sensor as well as its calibration curve $\left(1.0 \times 10^{-7}\right.$ to $5.0 \times 10^{-1}$ $\mathrm{M})$, which was obtained after measuring a series of praseodymium ion standard solutions. Subsequently, the $\operatorname{Pr}(\mathrm{III})$ ion concentration in the samples was determined.

\section{Electromotive force (EMF) measurements}

The EMF measurements with the polymeric membrane sensors were carried out with the cell assembly of (the activities were calculated in agreement with the Debye-Hückel procedure): ${ }^{17}$

$\mathrm{Ag}-\mathrm{AgCl} \| \mathrm{KCl}(3 \mathrm{M}) \mid$ internal solution, $1.0 \times 10^{-4} \mathrm{M} \mathrm{Pr}\left(\mathrm{NO}_{3}\right)_{3} \mid$ PVC membrane | test solution $\mid \mathrm{Hg}-\mathrm{Hg}_{2} \mathrm{Cl}_{2}, \mathrm{KCl}$ (Saturated).

\section{RESULTS AND DISCUSSION}

\section{Complexation of NAFT with some metal ions in acetonitrile solution}

In order to obtain an indication of the stability and selectivity of the complexes of NAFT with a number of alkali, alkaline earth, transition and heavy metal ions, a conductometric titration study in acetonitrile solution was performed. The more strongly the ionophore complexes with a given target ion, the larger the difference in the magnitude of the selectivity coefficients. In all measurements, the cell should be thermostated at a temperature of $25.0 \pm 0.1{ }^{\circ} \mathrm{C}$, using a Phywe immersion thermostat. In typical experiments, $25 \mathrm{~mL}$ of an ion solution $\left(1.0 \times 10^{-4} \mathrm{M}\right)$ is placed in a water-jacketed cell, equipped with a magnetic stirrer and connected to the thermostat, circulating water at the desired temperature. Then, a known amount of an ionophore $\left(1.0 \times 10^{-2} \mathrm{M}\right)$ solution is added in a stepwise manner, using a calibrated micropipette. The conductance of the solution is measured after each addition. The ionophore addition is continued until the desired ionophore-to-ion mole ratio is achieved. The 1:1 binding of the different cations with NAFT can be expressed by the following equilibrium:

$$
\begin{gathered}
M^{n+}+N A F T \rightarrow M-N A F T^{n+} \\
K_{f}=\frac{\left[M-N A F T^{n+}\right]}{\left[M^{n+}\right][N A F T]} \times \frac{f_{\left(M-N A F T^{n+}\right)}}{f_{\left(M^{n+}\right)} f_{(N A F T)}}
\end{gathered}
$$

The complex formation constancy in terms of the molar conductances, L, can be expressed as: ${ }^{18}$

$$
\begin{gathered}
K_{f}=\frac{\left[M-N A F T^{n+}\right]}{\left[M^{n+}\right][N A F T]}=\frac{\left(\Lambda_{M}-\Lambda_{o b s}\right)}{\left(\Lambda_{o b s}-\Lambda_{M-N A F T^{n+}}\right)[N A F T]} \\
{[N A F T]=C_{N A F T}-\frac{C_{M}\left(\Lambda_{M}-\Lambda_{o b s}\right)}{\left(\Lambda_{M}-\Lambda_{M-N A F T^{n+}}\right)}}
\end{gathered}
$$

where $\mathrm{L}_{\mathrm{M}}$ is the molar conductance of the metal ions before addition of NAFT, $\mathrm{L}_{\mathrm{M}-\mathrm{NAFT}}{ }^{\mathrm{n}+}$ the molar conductance of complexed ions, $\Lambda_{\text {obs }}$ the molar conductance of the solution during titration, $\mathrm{C}_{\mathrm{NAFT}}$ the analytical concentration of NAFT added, and $\mathrm{C}_{\mathrm{M}}$ the analytical concentration of the metal ions. The complex formation constants $\left(\mathrm{K}_{\mathrm{f}}\right)$ were evaluated by computer fitting of Equations 3 and 4 to the molar conductance-mole ratio data using a non-linear least-squares program Kinfit ${ }^{19}$ and the results are summarized in Table 1. As can be seen, the stability of the resulting complexes was varied in the order $\operatorname{Pr}^{3+}>>\mathrm{Cd}^{2+}>\mathrm{Ce}^{3+}>$ $\mathrm{Nd}^{3+}>\mathrm{La}^{3+}>\mathrm{Yb}^{3+}>\mathrm{Ho}^{3+} \sim \mathrm{Er}^{3+}>\mathrm{Lu}^{3+}>\mathrm{Sm}^{3+}>\mathrm{Pb}^{2+}>\mathrm{Eu}^{3+} \sim \mathrm{Tb}^{3+}>\mathrm{Gd}^{3+}>$ $\mathrm{Dy}^{3+}>\mathrm{Tm}^{3+}>\mathrm{Ba}^{2+}$ and was less than 2.0 for $\mathrm{Na}^{+}, \mathrm{K}^{+}, \mathrm{Cu}^{2+}, \mathrm{Cr}^{3+}$ and $\mathrm{Fe}^{3+}$. The conductometric results obtained revealed that NAFT can be used as a highly selective ionophore for the preparation of $\operatorname{Pr}(\mathrm{III})$ ion-selective membrane electrode.

Table 1. The formation constants of NAFT-M ${ }^{\mathrm{n}+}$ complexes at $25.0 \pm 0.1^{\circ} \mathrm{C}$

\begin{tabular}{cccc}
\hline Ion & $\log \mathrm{K}_{\mathrm{f}}$ & Ion & $\log \mathrm{K}_{\mathrm{f}}$ \\
\hline $\mathrm{Na}^{+}$ & $<2.0$ & $\mathrm{Nd}^{3+}$ & $2.89 \pm 0.02$ \\
$\mathrm{~K}^{+}$ & $<2.0$ & $\mathrm{Sm}^{3+}$ & $2.49 \pm 0.05$ \\
$\mathrm{Cu}^{2+}$ & $<2.0$ & $\mathrm{Eu}^{3+}$ & $2.40 \pm 0.03$ \\
$\mathrm{Cd}^{2+}$ & $3.06 \pm 0.04$ & $\mathrm{Gd}^{3+}$ & $2.22 \pm 0.04$ \\
$\mathrm{Ba}^{2+}$ & $2.10 \pm 0.03$ & $\mathrm{~Tb}^{3+}$ & $2.40 \pm 0.01$ \\
$\mathrm{~Pb}^{2+}$ & $2.46 \pm 0.03$ & $\mathrm{Dy}^{3+}$ & $2.17 \pm 0.05$ \\
$\mathrm{Cr}^{3+}$ & $<2.0$ & $\mathrm{Ho}^{3+}$ & $2.64 \pm 0.04$ \\
$\mathrm{Fe}^{3+}$ & $<2.0$ & $\mathrm{Er}^{3+}$ & $2.64 \pm 0.01$ \\
$\mathrm{La}^{3+}$ & $2.72 \pm 0.05$ & $\mathrm{Tm}^{3+}$ & $2.16 \pm 0.06$ \\
$\mathrm{Ce}^{3+}$ & $2.95 \pm 0.06$ & $\mathrm{Yb}^{3+}$ & $2.71 \pm 0.02$ \\
$\mathrm{Pr}^{3+}$ & $6.08 \pm 0.02$ & $\mathrm{Lu}^{3+}$ & $2.53 \pm 0.05$ \\
\hline
\end{tabular}

\section{Potential response of NAFT-based sensor}

In order to check the suitability of NAFT as an ion carrier for 
$\operatorname{Pr}(\mathrm{III})$ and other metal ions, experiments were carried out in which this ionophore was used in the construction of membrane sensors for lanthanide ions such as $\mathrm{Pr}^{3+}, \mathrm{Dy}^{3+}, \mathrm{Ce}^{3+}, \mathrm{Er}^{3+}, \mathrm{Gd}^{3+}$ and $\mathrm{Lu}^{3+}$, and other representative and transition metal ions such as $\mathrm{Cd}^{2+}, \mathrm{Cr}^{3+}, \mathrm{Pb}^{2+}$ and $\mathrm{K}^{+}$. The curves of the best potential responses of the resulting membranes versus the concentration of each ion, shown in Figure 2 , revealed that among the lanthanide, transition and representative ions tested, $\operatorname{Pr}(\mathrm{III})$ showed the highest response (with slope of 19.1 $\pm 0.4 \mathrm{mV} /$ decade) in the concentration range $1.0 \times 10^{-1}$ to $1.0 \times 10^{-5} \mathrm{M}$.

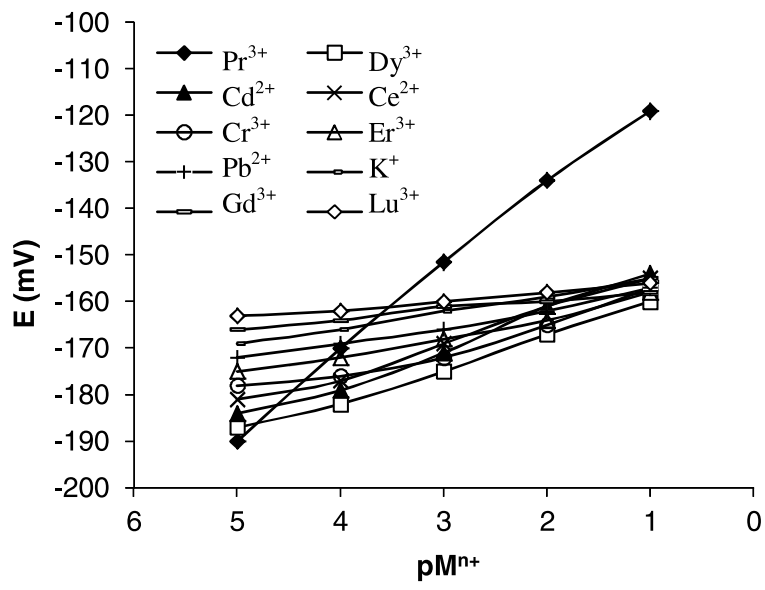

Figure 2. The potential response of various metals ion-selective electrodes based on NAFT

\section{Membrane composition influence on potential response of sensor}

It is well known that the sensitivity and selectivity obtained for a given ionophore depend greatly on the membrane composition and the nature of solvent mediator and additive used. ${ }^{4}$ Thus, the influences of the membrane composition, nature and amount of plasticizer, as well as amount of sodium tetra phenyl borate as lipophilic additives, on the potential response of the $\operatorname{Pr}(\mathrm{III})$ sensor were investigated. The composition of the membranes used in the ISE devices is typically around $30-33 \%$ (w/w) PVC and 60-66\% plasticizer. Such compositions exhibit optimal physical properties, ensuring relatively high mobilities for their constituents. The membrane solvent has to be physically compatible with the polymer, so as to give a homogeneous organic phase. Additionally, it may affect the selectivity behavior. ${ }^{6-9}$ Thus, in this work, eleven PVC membranes with plasticizer/PVC ratios of around 1.93-2.23, but with varying nature and amount of other ingredients, were prepared (Table 2).

The nature of plasticizer affects the response characteristics of the electrode, due to its influence on the dielectric constant of the membrane phase, the mobility of ionophore molecules and the state of the ligand. The potential response obtained for prepared membrane sensors with use of o-NPOE, BA, NB, DBP and AP at the same membrane composition (comprising NAFT - PVC - NaTPB - Plasticizer with the ratio 7.0: 30.0: 2.0: 61.0) is shown in Figure 3 . Due to the increased polarity of o-NPOE over BA, NB, DBP and $\mathrm{AP}$, it can be seen that membrane with o-NPOE as the plasticizer provided a better slope $(19.1 \pm 0.3 \mathrm{mV} /$ decade $)$ and higher order of magnitude, widening of the measuring concentration range of the corresponding membrane sensor over the membrane based on other plasticizers. Also, this result is in line with earlier reports showing that a high dielectric constant of plasticizers leads to better sensitivity to lanthanide(III) ions. ${ }^{5-11}$

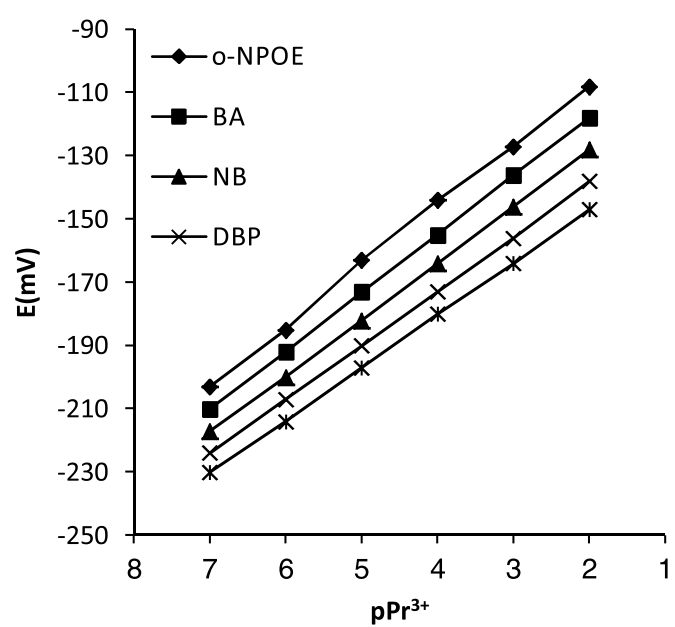

Figure 3. The potential responses of the Pr(III) membrane ISEs prepared with different plasticizers

The data given in Table 2 reveal that the presence of an additive has a beneficial effect on the performance characteristics of the membrane electrode. It has been confirmed experimentally that membranes without ionic impurities or deliberately added lipophilic ion exchangers show concentration-independent behavior if the sample contains only simple electrolytes. ${ }^{4}$ The addition of $3 \%$ NaTPB as a suitable additive will increase the slope of the potential response to

Table 2. Optimization of membrane ingredients during design of Pr(III) selective membrane sensor

\begin{tabular}{|c|c|c|c|c|c|c|}
\hline \multirow{2}{*}{ No. } & \multicolumn{4}{|c|}{ Composition (wt.\%) } & \multirow{2}{*}{ Slope (mV/decade) } & \multirow{2}{*}{ Linear range $(\mathrm{M})$} \\
\hline & PVC & Plasticizer & NAFT & Additive & & \\
\hline 1 & 30 & DBP, 61 & 7 & NaTPB, 2 & $17.8 \pm 0.3$ & $5.0 \times 10^{-6}$ to $1.0 \times 10^{-2}$ \\
\hline 2 & 30 & $\mathrm{NB}, 61$ & 7 & NaTPB, 2 & $18.1 \pm 0.5$ & $1.0 \times 10^{-6}$ to $5.0 \times 10^{-1}$ \\
\hline 3 & 30 & $\mathrm{BA}, 61$ & 7 & NaTPB, 2 & $18.5 \pm 0.1$ & $1.0 \times 10^{-6}$ to $1.0 \times 10^{-2}$ \\
\hline 4 & 30 & $o$-NPOE, 61 & 7 & NaTPB, 2 & $19.1 \pm 0.3$ & $5.0 \times 10^{-7}$ to $5.0 \times 10^{-1}$ \\
\hline 5 & 30 & AP, 61 & 7 & NaTPB, 2 & $16.6 \pm 0.2$ & $1.0 \times 10^{-5}$ to $5.0 \times 10^{-1}$ \\
\hline 6 & 30 & $o$-NPOE, 62 & 6 & NaTPB, 2 & $17.9 \pm 0.4$ & $1.0 \times 10^{-6}$ to $5.0 \times 10^{-1}$ \\
\hline 7 & 30 & $o$-NPOE, 60 & 8 & NaTPB, 2 & $19.7 \pm 0.1$ & $5.0 \times 10^{-7}$ to $5.0 \times 10^{-1}$ \\
\hline 8 & 30 & $o$-NPOE, 59 & 8 & NaTPB, 3 & $20.5 \pm 0.2$ & $1.0 \times 10^{-7}$ to $5.0 \times 10^{-1}$ \\
\hline 9 & 30 & $o$-NPOE, 58 & 8 & NaTPB, 4 & $20.1 \pm 0.4$ & $1.0 \times 10^{-7}$ to $5.0 \times 10^{-1}$ \\
\hline 10 & 30 & $o$-NPOE, 62 & 8 & - & $14.4 \pm 0.3$ & $5.0 \times 10^{-6}$ to $5.0 \times 10^{-1}$ \\
\hline 11 & 30 & $o$-NPOE, 67 & - & NaTPB, 3 & $7.8 \pm 0.3$ & $1.0 \times 10^{-5}$ to $1.0 \times 10^{-2}$ \\
\hline
\end{tabular}


a Nernstian value of $20.5 \mathrm{mV} / \mathrm{dec}$ de. The presence of an anionic additive, such as sodium tetra phenyl borate, can reduce the ohmic resistance and improve the response behavior and selectivity of the membrane electrode. ${ }^{4}$ Moreover, the additives may catalyze the exchange kinetics at the sample-membrane interface. Clearly, the best response characteristics were obtained with a membrane composition of 30\% PVC, 59\% o-NPOE, $8 \%$ NAFT and 3\% NaTPB (No. 8). The optimum responses of the electrodes were tested after conditioning (soaking) for different periods of time in $1.0 \times 10^{-4} \mathrm{M} \operatorname{Pr}(\mathrm{III})$ ions. Immersion in pure water should be avoided because it tends to leach out the $\operatorname{Pr}(\mathrm{III})$ ion from the membrane. Furthermore, this, together with the inherent instability of the liquid junction potential of the reference electrode, will cause an unstable voltage to be measured in pure water and require the membrane to be re-equilibrated in a high concentration preconditioning solution before it will give stable readings again. As can be seen in Table 3, the slopes obtained after conditioning for $18 \mathrm{~h}$ were close to the theoretical slopes expected on the basis of the Nernst equation. Longer conditioning times produced no further improvements in response.

Table 3. Effect of soaking time on the response characteristics of $\operatorname{Pr}(\mathrm{III})$ selective membrane sensor

\begin{tabular}{cc}
\hline Soaking time $(\mathrm{h})$ & Nernstian response range $(\mathrm{M})$ \\
\hline 6 & $1.0 \times 10^{-6}$ to $5.0 \times 10^{-3}$ \\
12 & $5.0 \times 10^{-7}$ to $1.0 \times 10^{-2}$ \\
18 & $1.0 \times 10^{-7}$ to $5.0 \times 10^{-1}$ \\
24 & $1.0 \times 10^{-7}$ to $5.0 \times 10^{-1}$ \\
\hline
\end{tabular}

\section{Calibration curve and statistical data}

The critical response characteristics of the $\operatorname{Pr}(\mathrm{III})$ sensor were assessed according to IUPAC recommendations..$^{20}$ The electrode shows a linear response to the activity of $\operatorname{Pr}(\mathrm{III})$ ions in the range $1.0 \times 10^{-7}$ to $5.0 \times 10^{-1} \mathrm{M}$ (Figure 4). A range of activity or concentration of cell response between the lower and upper detection limits is determined from a plot of the cell potential difference vs. the logarithm of primary ionic activity. The slope of the calibration graph was $20.5 \pm 0.2 \mathrm{mV} /$ decade. The limit of detection (its reliability determined by the cross point method) was $5.2 \times 10^{-8} \mathrm{M}$.

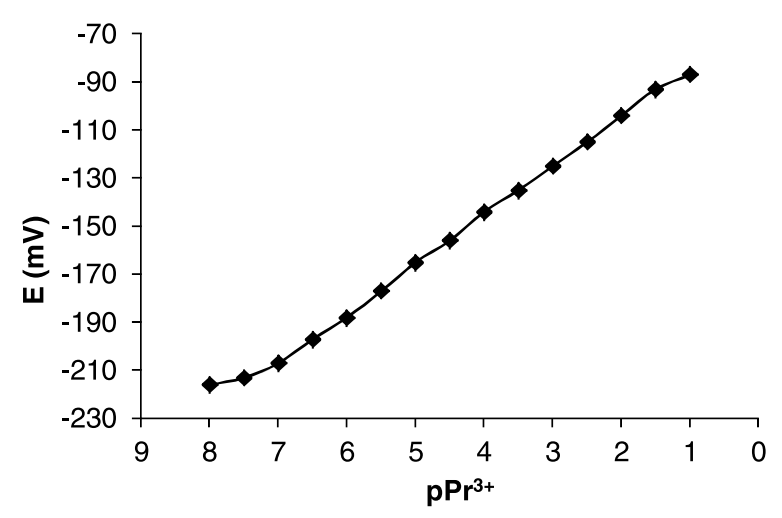

Figure 4. The calibration curve of the Pr(III) membrane sensor based on NAFT

\section{Effect of pH on electrode response}

The influence of $\mathrm{pH}$ on the potential response of the membrane electrode was studied over a $\mathrm{pH}$ range of $2.0-10.0$ for $1.0 \times 10^{-3} \mathrm{M}$ and $1.0 \times 10^{-4} \mathrm{M} \mathrm{Pr}\left(\mathrm{NO}_{3}\right)_{3}$ solutions. The $\mathrm{pH}$ was adjusted by introducing small drops of hydrochloric acid (0.1-0.01 M) or sodium hydroxide
(0.1-0.01 M). The results are illustrated in Figure 5. As can be seen, the potential was found to stay fairly constant in the $\mathrm{pH}$ range 3.0-8.8. In alkaline media $(\mathrm{pH}>8.8)$ however, a gradual change in potential was observed. The observed decrease in potential at higher $\mathrm{pH}$ values could be due to the formation of some hydroxyl complexes of $\operatorname{Pr}($ III) in solution. At lower $\mathrm{pH}$ values, the potentials increased, indicating that the membrane sensor also responds to protons.

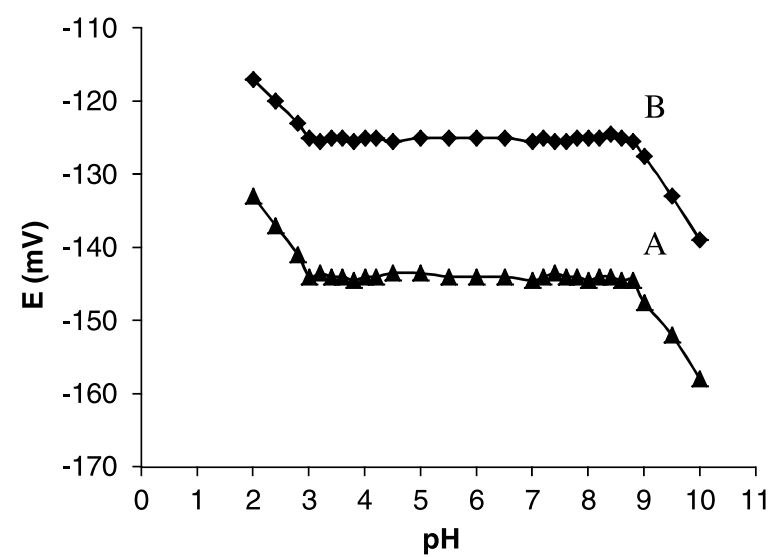

Figure 5. Effect of $p H$ on the potential response of the $\operatorname{Pr}(I I I)$ membrane sensor based on NAFT in the test solutions of $\operatorname{Pr}(I I I)$ ions: (A) $1.0 \times 10^{-4} \mathrm{M}$, (B) $1.0 \times 10^{-3} \mathrm{M}$

\section{Response time}

In earlier IUPAC recommendations, response time was defined as the time between the instant at which the ISE and a reference electrode are dipped in the sample solution and the first instant at which the potential of the cell becomes equal to its steady-state value within $1 \mathrm{mV}$ or has reached $90 \%$ of the final value. In this study, the practical response time was recorded by changing the praseodymium ion concentration in solution in the range $1.0 \times 10^{-7} \mathrm{M}$ to $1.0 \times 10^{-2} \mathrm{M}$ with results shown in Figure 6. The response time of the proposed membrane sensor was from $6 \mathrm{~s}$ (for high concentrations) to $9 \mathrm{~s}$ (for low concentrations) of $\operatorname{Pr}(\mathrm{III})$ ions. This is likely due to the fast exchange kinetics of complexation-decomplexation of $\operatorname{Pr}(\mathrm{III})$ with NAFT at the test solution-membrane interface.

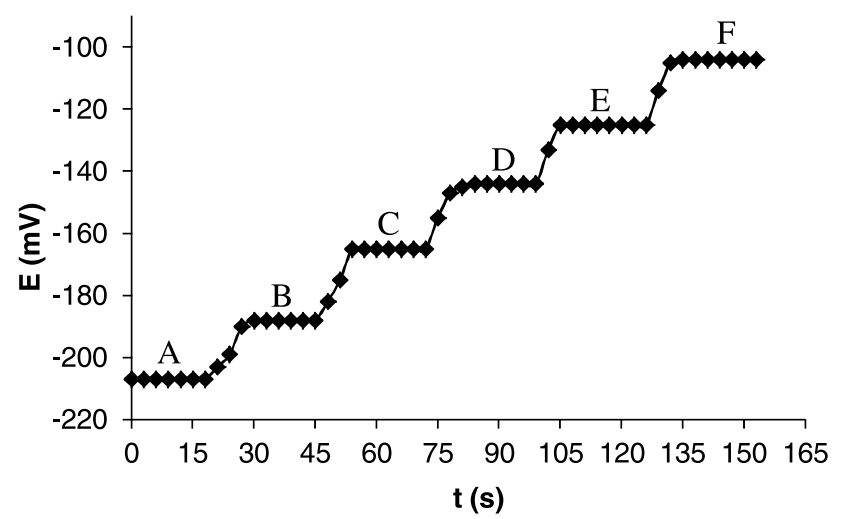

Figure 6. The practical response time of the $\operatorname{Pr}(I I I)$ membrane sensor for step changes in the $\operatorname{Pr}(\mathrm{III})$ concentration: (A) $1.0 \times 10^{-7} \mathrm{M}$, (B) $1.0 \times 10^{-6} \mathrm{M}$, (C) $1.0 \times 10^{-5} \mathrm{M}$, (D) $1.0 \times 10^{-4} \mathrm{M}$, (E) $1.0 \times 10^{-3} \mathrm{M}$, (F) $1.0 \times 10^{-2} \mathrm{M}$

\section{Determination of selectivity coefficient}

Selectivity is one of the most important characteristics of an electrode, as it often determines whether a reliable measurement in the sample is possible or otherwise. To investigate the membrane 
electrode selectivity, its potential response was monitored in the presence of various interfering foreign cations with the aid of the matched potential method (MPM). ${ }^{21}$ The resulting selectivity coefficient values are summarized in Table 4.

Table 4. The selectivity coefficients of various interfering cations for the membrane sensor

\begin{tabular}{cccc}
\hline Cation & $K_{\mathrm{Pr}^{3+}, B}^{M P M}$ & Cation & $K_{\mathrm{Pr}^{3+}, B}^{M P M}$ \\
\hline $\mathrm{Nd}^{3+}$ & $6.3 \times 10^{-3}$ & $\mathrm{Ba}^{2+}$ & $7.9 \times 10^{-4}$ \\
$\mathrm{Ce}^{3+}$ & $6.1 \times 10^{-3}$ & $\mathrm{Gd}^{3+}$ & $7.6 \times 10^{-4}$ \\
$\mathrm{Ho}^{3+}$ & $5.5 \times 10^{-3}$ & $\mathrm{Eu}^{3+}$ & $7.0 \times 10^{-4}$ \\
$\mathrm{Yb}^{3+}$ & $3.7 \times 10^{-3}$ & $\mathrm{~Tb}^{3+}$ & $6.7 \times 10^{-4}$ \\
$\mathrm{Cd}^{2+}$ & $2.2 \times 10^{-3}$ & $\mathrm{Fe}^{3+}$ & $5.1 \times 10^{-4}$ \\
$\mathrm{~Pb}^{2+}$ & $1.6 \times 10^{-3}$ & $\mathrm{~K}^{+}$ & $4.2 \times 10^{-4}$ \\
$\mathrm{Lu}^{3+}$ & $1.3 \times 10^{-3}$ & $\mathrm{Dy}^{3+}$ & $2.9 \times 10^{-4}$ \\
$\mathrm{La}^{3+}$ & $9.2 \times 10^{-4}$ & $\mathrm{Tm}^{3+}$ & $1.4 \times 10^{-4}$ \\
$\mathrm{Er}^{3+}$ & $8.8 \times 10^{-4}$ & $\mathrm{Cu}^{2+}$ & $8.9 \times 10^{-5}$ \\
$\mathrm{Cr}^{3+}$ & $8.4 \times 10^{-4}$ & $\mathrm{Al}^{3+}$ & $7.0 \times 10^{-6}$ \\
$\mathrm{Sm}^{3+}$ & $8.0 \times 10^{-4}$ & $\mathrm{Na}^{+}$ & $4.7 \times 10^{-6}$ \\
\hline
\end{tabular}

The data given in this table illustrate that the selectivity coefficients of the proposed $\operatorname{Pr}(\mathrm{III})$ membrane sensor for all the tested trivalent ions are $6.3 \times 10^{-3}$ or smaller, whereas for all the mono and divalent ions the selectivity coefficients are in the order of $3.7 \times 10^{-3}$ or smaller, which seems to indicate negligible interferences in the performance of the electrode assembly. Among the cations, $\mathrm{Nd}(\mathrm{III})$ was the major interfering ion in the determination of praseodymium ions. This means that when $\operatorname{Pr}(\mathrm{III})$ concentration is very low and $\mathrm{Nd}(\mathrm{III})$ concentration is high (around 10 or 100 times greater), the potential response of the electrode is changed very slightly and introduces negligible error in the determination of the $\operatorname{Pr}(\mathrm{III})$ ions because the membrane sensor responds to $\mathrm{Nd}$ (III) as if it were $\mathrm{Pr}(\mathrm{III})$. Therefore, the apparent $\operatorname{Pr}(\mathrm{III})$ concentration is higher.

\section{Sensor lifetime}

For the investigation of the stability and lifetime of the $\operatorname{Pr}(\mathrm{III})$ membrane sensor, two electrodes were tested over a period of 15 weeks and the results given in Table 5. The main factor limiting the lifetime of the ion-selective membrane in potentiometric measurements is the leakage of ionophore into the aqueous solutions. The proposed PVC-based membrane sensor could be used for at least 12 weeks (use of $1 \mathrm{~h}$ daily). After its utilization, it was washed and kept dry. During the time period specified, the membrane sensor could be used without any measurable divergence whereas after this period, changes were observed in the slope and detection limit (from 20.5 to $19.5 \mathrm{mV} /$ decade and $1.3 \times 10^{-7}$ from $7.1 \times 10^{-8} \mathrm{M}$, respectively).

\section{Analytical applications}

The membrane sensor was successfully used in the potentiometric titration of $\operatorname{Pr}(\mathrm{III})$ with EDTA. As evident from Figure 7, the sharp break point corresponds to the stoichiometry of the Pr(III)-EDTA complex.

The recovery tests were performed using 3 different samples (tap, mineral and river water) using the spike method. The test for each sample was carried out using triplicate measurements. As is clear from Table $6, \operatorname{Pr}(\mathrm{III})$ can be accurately recovered from the solutions at between 100.8 and $104.5 \%$. The proposed sensor was
Table 5. Lifetime of $\operatorname{Pr}(\mathrm{III})$ selective membrane sensor

\begin{tabular}{ccl}
\hline Week & Slop $(\mathrm{mV} /$ decade $)$ & $\mathrm{DL}^{\mathrm{a}}(\mathrm{M})$ \\
\hline 1 & $20.7 \pm 0.2$ & $5.2 \times 10^{-8}$ \\
2 & $20.8 \pm 0.4$ & $5.3 \times 10^{-8}$ \\
3 & $20.7 \pm 0.3$ & $5.2 \times 10^{-8}$ \\
4 & $20.6 \pm 0.1$ & $5.3 \times 10^{-8}$ \\
5 & $20.6 \pm 0.5$ & $5.4 \times 10^{-8}$ \\
6 & $20.4 \pm 0.5$ & $5.5 \times 10^{-8}$ \\
7 & $20.5 \pm 0.2$ & $5.6 \times 10^{-8}$ \\
8 & $20.5 \pm 0.1$ & $5.6 \times 10^{-8}$ \\
9 & $20.4 \pm 0.3$ & $5.8 \times 10^{-8}$ \\
10 & $20.4 \pm 0.4$ & $6.3 \times 10^{-8}$ \\
11 & $20.6 \pm 0.4$ & $6.7 \times 10^{-8}$ \\
12 & $20.5 \pm 0.2$ & $7.1 \times 10^{-8}$ \\
13 & $19.5 \pm 0.4$ & $1.3 \times 10^{-7}$ \\
14 & $19.1 \pm 0.2$ & $1.9 \times 10^{-7}$ \\
15 & $18.8 \pm 0.1$ & $3.1 \times 10^{-7}$ \\
\hline & & \\
\hline & &
\end{tabular}

a Detection limit

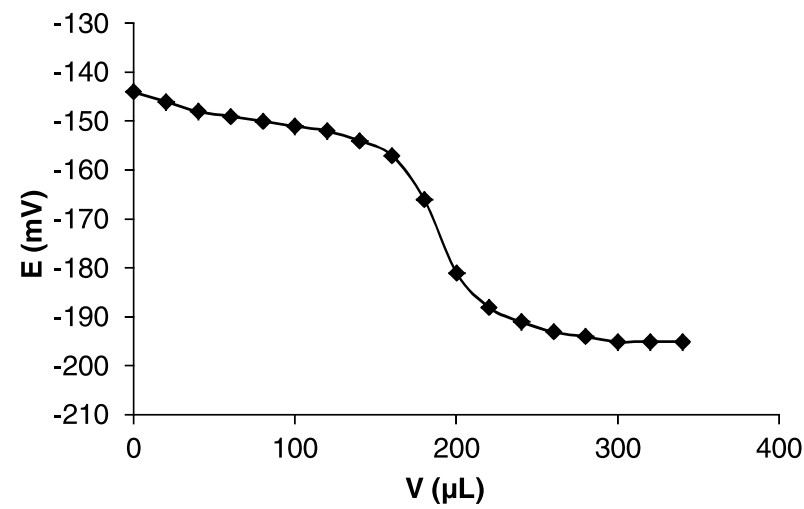

Figure 7. Potential titration curve of $20.0 \mathrm{~mL}$ from a $1.0 \times 10^{-4} \mathrm{M} \operatorname{Pr}(\mathrm{III})$ solution with $1.0 \times 10^{-2} \mathrm{M}$ of EDTA

used for the determination of fluoride ion concentration in two mouth wash preparations. ${ }^{14,22}$ One $\mathrm{g}$ of each sample of the sodium fluoride mouth wash solutions (Aquafresh, Brentford, UK and Eurodont, Dr. Scheller, DuroDont GmbH, Germany) was taken and diluted with distilled water in a $100 \mathrm{~mL}$ flask and titrated with a $\operatorname{Pr}(\mathrm{III})$ solution $\left(1.0 \times 10^{-3} \mathrm{M}\right)$.

Table 6. Results of the recovery of $\operatorname{Pr}(\mathrm{III})$ ions in the three samples by spike method

\begin{tabular}{lcccc}
\hline Sample & $\begin{array}{c}\operatorname{Pr}(\mathrm{III}) \text { added } \\
(\mu \mathrm{M})\end{array}$ & $\begin{array}{c}\operatorname{Pr}(\mathrm{III}) \text { found }^{\mathrm{a}} \\
(\mu \mathrm{M})\end{array}$ & $\begin{array}{c}\text { R.S.D } \\
(\%)\end{array}$ & $\begin{array}{c}\text { Recovery } \\
(\%)\end{array}$ \\
\hline Tap sample & 0.00 & $\mathrm{ND}^{\mathrm{b}}$ & - & - \\
& 1.50 & 1.58 & 1.2 & $104.5 \pm 0.1$ \\
River water & 0.00 & $\mathrm{ND}$ & - & - \\
& 1.00 & 1.04 & 1.1 & $104.0 \pm 0.2$ \\
Mineral water & 0.00 & $\mathrm{ND}$ & - & - \\
& 0.500 & 0.504 & 1.1 & $100.8 \pm 0.6$ \\
\hline
\end{tabular}

${ }^{\mathrm{a}}$ Results are based on three measurements. ${ }^{\mathrm{b}}$ Not detected

The corresponding results (after triplicate measurements) are summarized in Table 7. Evidently, there is a satisfactory agreement 
Table 7. Determination of fluoride ions in mouth washes

\begin{tabular}{lccc}
\hline Sample & $\begin{array}{c}\text { Labeled } \\
(\mu \mathrm{g} / \mathrm{mL})\end{array}$ & $\begin{array}{c}\text { Found ISE } \\
(\mu \mathrm{g} / \mathrm{mL})\end{array}$ & $\begin{array}{c}\text { Commercial fluoride } \\
\mathrm{ISE}^{\mathrm{b}}(\mu \mathrm{g} / \mathrm{mL})\end{array}$ \\
\hline Sodium fluoride mouth wash solution (Aquafresh, Brentford, UK) & 1350 & $1368 \pm 19$ & $1348 \pm 11$ \\
Sodium fluoride mouth wash solution (Eurodont, DuroDont GmbH) & 1450 & $1473 \pm 13$ & $1446 \pm 15$ \\
\hline
\end{tabular}

${ }^{\mathrm{a}}$ Designed Pr(III) membrane sensor. ${ }^{\mathrm{b}}$ Results are based on 3 measurements

among the declared fluoride content, the values determined by the developed sensor, and the commercial solid fluoride sensor.

Monazite $\left[(\mathrm{Ln}, \mathrm{Th}) \mathrm{PO}_{4}\right]$, Bastnasite $\left[\mathrm{LnFCO}_{3}\right]$ and Xenotime $\left[(\mathrm{Y}, \mathrm{Ln}) \mathrm{PO}_{4}\right]$ are three important lanthanide ores and there were large amounts of these elements. The first and second are richer in earlier lanthanides while the last is richer in later lanthanides. Thus, 3 solutions were prepared with the same ingredients of monazite, bastnasite and xenotime and diluted 1000 times to provide sample solutions (due to the amounts of praseodymium in monazite and bastnasite being so large, they were inevitably diluted 10 times more). The results obtained for $\operatorname{Pr}(\mathrm{III})$ ions in the samples under investigation are given in Table 8 .

Table 8. Comparison between the determination of $\operatorname{Pr}(\mathrm{III})$ ions by proposed sensor, ICP-AES and FFT-CCV

\begin{tabular}{ccccc}
\hline \multirow{2}{*}{ Solution } & \multirow{2}{*}{$\begin{array}{c}\text { Real amount } \\
(\mu \mathrm{g} / \mathrm{mL})\end{array}$} & \multicolumn{3}{c}{ Found amount $(\mu \mathrm{g} / \mathrm{mL})$} \\
\cline { 3 - 5 } & 4.5 & $4.56 \pm 0.15$ & $4.53 \pm 0.21$ & $4.66 \pm 0.14$ \\
Monazite & 4.3 & $4.36 \pm 0.12$ & $4.38 \pm 0.19$ & $4.40 \pm 0.21$ \\
Bastnasite & 7.0 & $7.15 \pm 0.09$ & $7.11 \pm 0.06$ & $7.12 \pm 0.05$ \\
Xenotime & 7.0 &
\end{tabular}

${ }^{\mathrm{a}}$ Designed Pr(III) membrane sensor. ${ }^{\mathrm{b}}$ Results are based on 3 measurements

For these determinations, three replicate analyses were performed for each sample. From the results. it can be seen that within the precision of both measuring procedures, the concentration values of these ions determined by the proposed sensor, ICP-AES and fast Fourier transform continuous cyclic voltammetry (FFT-CCV) ${ }^{23}$ are in fairly good agreement with each other. The proposed sensor was effectively employed for the determination of praseodymium ions in soil and sediment samples. ${ }^{24}$ The result, derived from triplicate measurements with the same sensor, was found to be in satisfactory agreement with that determined by the Arsenazo method, as seen in Table 9. This is a spectrophotometric method in which the Arsenazo reagent (o-(1,8-dihydroxy-3,6-disulfo- 2-naphthylazo)benzene arsenic acid, tri-sodium salt) forms a colored complex with the lanthanide ions and is also used as a standard method for determination of lanthanides.

Table 9. Determination of Pr(III) ions in soil samples

\begin{tabular}{ccc}
\hline Sample No. & $\begin{array}{c}\text { Designed membrane sensor } \\
(\mu \mathrm{g} / \mathrm{mL})\end{array}$ & $\begin{array}{c}\text { Arsenazomethod }^{\mathrm{a}} \\
(\mu \mathrm{g} / \mathrm{mL})\end{array}$ \\
\hline 1 & $53.1 \pm 0.2$ & $52.9 \pm 0.3$ \\
2 & $39.5 \pm 0.5$ & $39.6 \pm 0.5$ \\
3 & $43.9 \pm 0.4$ & $43.5 \pm 0.2$ \\
4 & $22.7 \pm 0.1$ & $22.7 \pm 0.2$ \\
5 & $64.3 \pm 0.1$ & $64.0 \pm 0.4$ \\
\hline
\end{tabular}

${ }^{a}$ Results are based on 3 measurements

There was a color change from red-orange to blue-violet, denoting the complex formation. ${ }^{25}$ The $\mathrm{pH}$ range, linear range, detection limit, slope and selectivity coefficients of the proposed sensor, in addition to some of those previously reported that used $\operatorname{Pr}(\mathrm{III})$ membrane selective electrodes ${ }^{10,11}$, are compared in Table 10.

Table 10. Comparative data from published methods on $\operatorname{Pr}(\mathrm{III})$ ion selective electrodes

\begin{tabular}{|c|c|c|c|c|c|}
\hline $\mathrm{pH}$ range & Linear Range (M) & DL (M) & Slope $^{\mathrm{a}}$ & Selectivity coefficients ${ }^{\mathrm{b}}$ & Ref \\
\hline 3.5 to 8.0 & $1.0 \times 10^{-6}$ to $1.0 \times 10^{-2}$ & $8.0 \times 10^{-7}$ & 21.1 & $\begin{array}{l}\mathrm{La}^{3+}(2.12), \mathrm{Ce}^{3+}(2.00), \mathrm{Nd}^{3+}(2.22), \mathrm{Sm}^{3+}(1.46), \mathrm{Eu}^{3+}(1.60), \mathrm{Gd}^{3+}(2.00), \\
\mathrm{Dy}^{3+}(2.52), \mathrm{Ho}^{3+}(2.68), \mathrm{Er}^{3+}(1.40), \mathrm{Tm}^{3+}(3.35), \mathrm{Yb}^{3+}(3.82), \mathrm{Lu}^{3+}(1.52), \\
\mathrm{Na}^{+}(3.96), \mathrm{Mg}^{2+}(3.46), \mathrm{K}^{+}(3.82), \mathrm{Ca}^{2+}(3.35) \\
\text { By MPM method }\end{array}$ & 10 \\
\hline 3.5 to 8.5 & $1.0 \times 10^{-8}$ to $1.0 \times 10^{-3}$ & $7.0 \times 10^{-9}$ & 19.8 & $\begin{array}{l}\mathrm{La}^{3+}(4.60), \mathrm{Ce}^{3+}(4.00), \mathrm{Nd}^{3+}(4.39), \mathrm{Sm}^{3+}(3.45), \mathrm{Eu}^{3+}(4.60), \mathrm{Gd}^{3+}(3.52), \\
\mathrm{Dy}^{3+}(3.45), \mathrm{Ho}^{3+}(4.67), \mathrm{Tm}^{3+}(3.34), \mathrm{Yb}^{3+}(3.82), \mathrm{Lu}^{3+}(3.52), \mathrm{Na}^{+}(3.38), \\
\mathrm{Mg}^{2+}(4.18), \mathrm{Pb}^{2+}(4.34) \\
\text { By MPM method }\end{array}$ & $11\left(1^{\mathrm{st}}\right)$ \\
\hline 3.0 to 8.4 & $1.6 \times 10^{-6}$ to $1.0 \times 10^{-2}$ & $2.0 \times 10^{-6}$ & 19.8 & $\begin{array}{c}\mathrm{La}^{3+}(3.00), \mathrm{Nd}^{3+}(3.09), \mathrm{Sm}^{3+}(2.88), \mathrm{Eu}^{3+}(3.01), \mathrm{Gd}^{3+}(3.45), \mathrm{Dy}^{3+}(3.11), \\
\mathrm{Al}^{3+}(2.76), \mathrm{K}^{+}(2.30), \mathrm{Cr}^{3+}(2.42), \mathrm{Fe}^{3+}(2.65), \mathrm{Sr}^{2+}(3.22) \\
\underline{\text { By FPM}} \underline{\text { method }}\end{array}$ & $11\left(2^{\text {nd }}\right)$ \\
\hline \multirow[t]{2}{*}{3.5 to 8.0} & $2.0 \times 10^{-8}$ to $1.0 \times 10^{-2}$ & $5.0 \times 10^{-9}$ & 20.0 & $\begin{array}{l}\mathrm{La}^{3+}(3.84), \mathrm{Ce}^{3+}(4.18), \mathrm{Nd}^{3+}(4.50), \mathrm{Sm}^{3+}(3.16), \mathrm{Eu}^{3+}(4.85), \mathrm{Gd}^{3+}(4.20), \\
\mathrm{Ho}^{3+}(4.76), \mathrm{Tm}^{3+}(3.57), \mathrm{Yb}^{3+}(4.05), \mathrm{Lu}^{3+}(3.80), \mathrm{Na}^{+}(3.40), \mathrm{K}^{+}(3.85), \\
\mathrm{Zn}^{2+}(1.91), \mathrm{Pb}^{2+}(4.30)\end{array}$ & $11\left(3^{\text {rd }}\right)$ \\
\hline & & & & By FIM $\underline{\underline{d}} \underline{\text { method }}$ & \\
\hline \multirow[t]{2}{*}{3.1 to 9.8} & $1.0 \times 10^{-6}$ to $1.0 \times 10^{-2}$ & $5.7 \times 10^{-7}$ & 19.8 & $\begin{array}{l}\mathrm{La}^{3+}(2.17), \mathrm{Nd}^{3+}(3.09), \mathrm{Sm}^{3+}(2.42), \mathrm{Eu}^{3+}(3.09), \mathrm{Gd}^{3+}(3.49), \mathrm{Tb}^{3+}(3.32), \\
\mathrm{Dy}^{3+}(3.60), \mathrm{Ho}^{3+}(3.06), \mathrm{Er}^{3+}(3.38), \mathrm{Tm}^{3+}(3.28), \mathrm{Yb}^{3+}(2.58), \mathrm{Lu}^{3+}(3.19), \\
\mathrm{Na}^{+}(3.62), \mathrm{K}^{+}(3.44), \mathrm{Ca}^{2+}(3.64), \mathrm{Cr}^{3+}(3.35), \mathrm{Fe}^{3+}(3.47), \mathrm{Co}^{2+}(3.14), \\
\mathrm{Ni}^{2+}(3.17), \mathrm{Pb}^{2+}(3.33)\end{array}$ & $11\left(4^{\text {th }}\right)$ \\
\hline & & & & By MPM method & \\
\hline 3.0 to 8.8 & $1.0 \times 10^{-7}$ to $5.0 \times 10^{-1}$ & $5.2 \times 10^{-8}$ & 20.5 & $\begin{array}{l}\mathrm{Ce}^{3+}(2.21), \mathrm{Nd}^{3+}(2.20), \mathrm{Sm}^{3+}(3.10), \mathrm{Eu}^{3+}(3.15), \mathrm{Gd}^{3+}(3.12), \mathrm{Tb}^{3+}(3.17), \\
\mathrm{Dy}^{3+}(3.54), \mathrm{Ho}^{3+}(2.26), \mathrm{Er}^{3+}(3.06), \mathrm{Tm}^{3+}(3.85), \mathrm{Yb}^{3+}(2.43), \mathrm{Lu}^{3+}(2.89), \\
\mathrm{Na}^{+}(5.33), \mathrm{Al}^{3+}(5.15), \mathrm{K}^{+}(3.38), \mathrm{Cr}^{3+}(3.08), \mathrm{Fe}^{3+}(3.29), \mathrm{Cu}^{2+}(4.05), \\
\mathrm{Cd}^{2+}(2.66), \mathrm{Ba}^{2+}(3.10), \mathrm{Pb}^{2+}(2.80) \\
\text { By MPM method }\end{array}$ & This work \\
\hline
\end{tabular}


Table 10. continuation

\begin{tabular}{|c|c|c|c|c|c|}
\hline $\mathrm{pH}$ range & Linear Range (M) & DL (M) & Slope ${ }^{a}$ & Selectivity coefficients ${ }^{\mathrm{b}}$ & Ref \\
\hline 3.5 to 8.0 & $1.0 \times 10^{-6}$ to $1.0 \times 10^{-2}$ & $8.0 \times 10^{-7}$ & 21.1 & $\begin{array}{l}\mathrm{La}^{3+}(2.12), \mathrm{Ce}^{3+}(2.00), \mathrm{Nd}^{3+}(2.22), \mathrm{Sm}^{3+}(1.46), \mathrm{Eu}^{3+}(1.60), \mathrm{Gd}^{3+}(2.00), \\
\mathrm{Dy}^{3+}(2.52), \mathrm{Ho}^{3+}(2.68), \mathrm{Er}^{3+}(1.40), \mathrm{Tm}^{3+}(3.35), \mathrm{Yb}^{3+}(3.82), \mathrm{Lu}^{3+}(1.52), \\
\mathrm{Na}^{+}(3.96), \mathrm{Mg}^{2+}(3.46), \mathrm{K}^{+}(3.82), \mathrm{Ca}^{2+}(3.35) \\
\text { By MPM method }\end{array}$ & 10 \\
\hline 3.5 to 8.5 & $1.0 \times 10^{-8}$ to $1.0 \times 10^{-3}$ & $7.0 \times 10^{-9}$ & 19.8 & $\begin{array}{l}\mathrm{La}^{3+}(4.60), \mathrm{Ce}^{3+}(4.00), \mathrm{Nd}^{3+}(4.39), \mathrm{Sm}^{3+}(3.45), \mathrm{Eu}^{3+}(4.60), \mathrm{Gd}^{3+}(3.52), \\
\mathrm{Dy}^{3+}(3.45), \mathrm{Ho}^{3+}(4.67), \mathrm{Tm}^{3+}(3.34), \mathrm{Yb}^{3+}(3.82), \mathrm{Lu}^{3+}(3.52), \mathrm{Na}^{+}(3.38), \\
\mathrm{Mg}^{2+}(4.18), \mathrm{Pb}^{2+}(4.34) \quad \text { By MPM method }\end{array}$ & $11\left(1^{\mathrm{st}}\right)$ \\
\hline 3.0 to 8.4 & $1.6 \times 10^{-6}$ to $1.0 \times 10^{-2}$ & $2.0 \times 10^{-6}$ & 19.8 & $\begin{array}{c}\mathrm{La}^{3+}(3.00), \mathrm{Nd}^{3+}(3.09), \mathrm{Sm}^{3+}(2.88), \mathrm{Eu}^{3+}(3.01), \mathrm{Gd}^{3+}(3.45), \mathrm{Dy}^{3+}(3.11), \\
\mathrm{Al}^{3+}(2.76), \mathrm{K}^{+}(2.30), \mathrm{Cr}^{3+}(2.42), \mathrm{Fe}^{3+}(2.65), \mathrm{Sr}^{2+}(3.22) \\
\text { By FPM } \underline{\text { method }}\end{array}$ & $11\left(2^{\text {nd }}\right)$ \\
\hline 3.5 to 8.0 & $2.0 \times 10^{-8}$ to $1.0 \times 10^{-2}$ & $5.0 \times 10^{-9}$ & 20.0 & $\begin{array}{l}\mathrm{La}^{3+}(3.84), \mathrm{Ce}^{3+}(4.18), \mathrm{Nd}^{3+}(4.50), \mathrm{Sm}^{3+}(3.16), \mathrm{Eu}^{3+}(4.85), \mathrm{Gd}^{3+}(4.20), \\
\mathrm{Ho}^{3+}(4.76), \mathrm{Tm}^{3+}(3.57), \mathrm{Yb}^{3+}(4.05), \mathrm{Lu}^{3+}(3.80), \mathrm{Na}^{+}(3.40), \mathrm{K}^{+}(3.85), \\
\mathrm{Zn}^{2+}(1.91), \mathrm{Pb}^{2+}(4.30) \quad \text { By FIM } \\
\end{array}$ & $11\left(3^{\mathrm{rd}}\right)$ \\
\hline 3.1 to 9.8 & $1.0 \times 10^{-6}$ to $1.0 \times 10^{-2}$ & $5.7 \times 10^{-7}$ & 19.8 & $\begin{array}{l}\mathrm{La}^{3+}(2.17), \mathrm{Nd}^{3+}(3.09), \mathrm{Sm}^{3+}(2.42), \mathrm{Eu}^{3+}(3.09), \mathrm{Gd}^{3+}(3.49), \mathrm{Tb}^{3+}(3.32), \\
\mathrm{Dy}^{3+}(3.60), \mathrm{Ho}^{3+}(3.06), \mathrm{Er}^{3+}(3.38), \mathrm{Tm}^{3+}(3.28), \mathrm{Yb}^{3+}(2.58), \mathrm{Lu}^{3+}(3.19), \\
\mathrm{Na}^{+}(3.62), \mathrm{K}^{+}(3.44), \mathrm{Ca}^{2+}(3.64), \mathrm{Cr}^{3+}(3.35), \mathrm{Fe}^{3+}(3.47), \mathrm{Co}^{2+}(3.14), \\
\mathrm{Ni}^{2+}(3.17), \mathrm{Pb}^{2+}(3.33) \quad \text { By MPM method }\end{array}$ & $11\left(4^{\text {th }}\right)$ \\
\hline 3.0 to 8.8 & $1.0 \times 10^{-7}$ to $5.0 \times 10^{-1}$ & $5.2 \times 10^{-8}$ & 20.5 & $\begin{array}{l}\mathrm{Ce}^{3+}(2.21), \mathrm{Nd}^{3+}(2.20), \mathrm{Sm}^{3+}(3.10), \mathrm{Eu}^{3+}(3.15), \mathrm{Gd}^{3+}(3.12), \mathrm{Tb}^{3+}(3.17), \\
\mathrm{Dy}^{3+}(3.54), \mathrm{Ho}^{3+}(2.26), \mathrm{Er}^{3+}(3.06), \mathrm{Tm}^{3+}(3.85), \mathrm{Yb}^{3+}(2.43), \mathrm{Lu}^{3+}(2.89), \\
\mathrm{Na}^{+}(5.33), \mathrm{Al}^{3+}(5.15), \mathrm{K}^{+}(3.38), \mathrm{Cr}^{3+}(3.08), \mathrm{Fe}^{3+}(3.29), \mathrm{Cu}^{2+}(4.05), \\
\mathrm{Cd}^{2+}(2.66), \mathrm{Ba}^{2+}(3.10), \mathrm{Pb}^{2+}(2.80) \\
\text { By MPM method }\end{array}$ & This work \\
\hline
\end{tabular}

${ }^{\mathrm{a}} \mathrm{mV} /$ decade. ${ }^{\mathrm{b}}\left(-\log K_{\mathrm{Pr}^{\mathrm{P}}, B}^{\mathrm{Pot}}\right) \cdot{ }^{\mathrm{c}}$ Fixed Primary ion Method. ${ }^{\mathrm{f}}$ Fixed Interference Method

\section{CONCLUSION}

A simple construction procedure was used to develop ion selective electrodes for the detection of $\operatorname{Pr}(\mathrm{III})$ ions at low concentrations. The use of 3-nitro-4-amino-5-naphtho[2,1-b]furan-2-yl-4H-1,2,4-triazole-3-thiol (NAFT) with o-NPOE as a plasticizer showed the best response characteristics with Nernstian behavior over the concentration range of $1.0 \times 10^{-7}-5.0 \times 10^{-1} \mathrm{M} \operatorname{Pr}(\mathrm{III})$, a detection limit of $5.2 \times 10^{-8} \mathrm{M}$ with very low interference from common alkali, alkaline earth, transition and heavy metal ions, and a fast response time of $\sim 8 \mathrm{~s}$. The proposed sensor potential responses are independent of $\mathrm{pH}$ in the range 3.0-8.8. The lipophilicity of the ionophore, drastically decreasing its leaching from the membrane to the test solution, is the reason for the long life-times of the electrodes based on NAFT. All these advantages, together with the other improvements resulting from the optimized composition of the membrane ingredients, render NAFT-based membrane sensors acceptable potentiometric devices for the determination of $\operatorname{Pr}(\mathrm{III})$ concentrations in different samples.

\section{REFERENCES}

1. Jennifer, J. N.; Peek Jennifer, J.; James, E. S.; Eur. J. Glass Sci. Technol. Part B 2007, 48, 79.

2. http://www.britannica.com, accessed January 2012.

3. Shamsipur, M.; Yousefi, M.; Ganjali, M. R.; Anal. Chem. 2001, 72, 2391; Ganjali, M. R.; Pourjavid, M. R.; Shamsipur, M.; Poursaberi, T.; Rezapour, M.; Javanbakht, M.; Sharghi, M.; Anal. Sci. 2003, 19, 995; Ganjali, M. R.; Rezapour, M.; Pourjavid, M. R.; Salavati-Niasari, M.; Anal. Sci. 2003, 19, 1127; Ganjali, M. R.; Kiani-Anbouhi, R.; Pourjavid, M. R.; Salavati-Niasari, M.; Talanta 2003, 61, 277; Ganjali, M. R.; Daftari, A.; Pourjavid, M. R.; FaalRastegar, M.; Moghimi, A.; Main Group Met. Chem. 2002, 25, 669; Masrournia, M.; Zamani, H. A.; Mirrashid, H. A.; Ganjali, M. R.; Faridbod, F.; Mater. Sci. Eng.: C 2011, 31, 574.

4. Bakker, E.; Bühlmann, P.; Pretsch, E.; Chem. Rev. 1997, 97, 3083; Bühlmann, P.; Pretsch, E.; Bakker, E.; Chem. Rev. 1998, 98, 1593;
Bakker, E.; Bühlmann, P.; Pretsch, E.; Electroanalysis 1998, 11, 915; Bakker, E.; Pretsch, E.; Bühlmann, P.; Anal. Chem. 2000, 72, 1127.

5. Ganjali, M. R.; Norouzi, P.; Rezapour, M.; Faridbod, F.; Pourjavid, M. R.; Sensors 2006, 6, 1018; Ganjali, M. R.; Norouzi, P.; Faridbod, F.; Rezapour, M.; Pourjavid, M.R.; J. Iran. Chem. Soc. 2007, 4, 1.

6. Ganjali, M. R.; Pourjavid, M. R.; Mouradzadegun, A.; Hosseini, M.; Mizani, F.; Bull. Korean Chem. Soc. 2003, 24, 1585; Ganjali, M. R.; Pourjavid, M. R.; Rezapour, M.; Poursaberi, T.; Daftari, A.; SalavatiNiasari, M.; Electroanalysis 2004, 16, 922.

7. Ganjali, M. R.; Pourjavid, M. R.; Rezapour, M.; Haghgoo, S.; Sens. Actuators, B 2003, 89, 21; Ganjali, M. R.; Rezapour, M.; Pourjavid, M. R.; Haghgoo, S.; Anal. Sci. 2004, 20, 1007; Ganjali, M. R.; Ghesmi, A.; Hosseini, M.; Pourjavid, M. R.; Rezapour, M.; Shamsipur, M.; Salavati-Niasari, M.; Sens. Actuators, B 2005, 105, 334; Ganjali, M. R.; Ravanshad, J.; Hoseini, M.; Salavati-Niasari, M.; Pourjavid, M. R.; Baezzate, M. R.; Electroanalysis 2004, 16, 1771.

8. Gupta, V. K.; Pal, M. K.; Singh, A. K.; Talanta 2009, 79, 528; Ganjali, M. R.; Faridbod, F.; Norouzi, P.; Adib, M.; Sens. Actuators, B 2006, 120, 119; Behmadi, H.; Zamani, H. A.; Ganjali, M. R.; Norouzi, P.; Electrochim. Acta 2007, 53, 1870; Zamani, H. A.; Nekoei, M.; Mohammadhosseini, M.; Ganjali, M. R.; Mater. Sci. Eng.: C 2010, 30, 480.

9. Ganjali, M. R.; Norouzi, P.; Atrian, A. R.; Faridbod, F.; Meghdadi, S.; Giahi, M.; Mater. Sci. Eng.: C 2009, 29, 205; Zamani, H. A.; Feizyzadeh, B.; Faridbod, F.; Ganjali, M. R.; Mater. Sci. Eng.: C 2011, 31, 1379; Zamani, H. A.; Imani, A.; Arvinfar, A.; Rahimi, F.; Ganjali, M. R.; Faridbod, F.; Meghdadi, S.; Mater. Sci. Eng.: C 2011, 31, 588; Zamani, H. A.; Rohani, M.; Zangeneh-Asadabadi, A.; Zabihi, M. S.; Ganjali, M. R.; Salavati-Niasari, M.; Mater. Sci. Eng.: C 2010, 30, 917.

10. Ganjali, M. R.; Mirnaghi, F. S.; Norouzi, P.; Adib, M.; Sens. Actuators, $B$ 2006, 115, 374.

11. Ganjali, M. R.; Norouzi, P.; Mirnaghi, F. S.; Riahi, S.; Faridbod, F.; Sens. J. IEEE 2007, 7, 1138; Zamani, H. A.; Ganjali, M. R.; Norouzi, P.; Meghdadi, S.; Anal. Lett. 2008, 41, 902; Gupta, V. K.; Goyal, R. N.; Pal, M. K.; Sharma, R. A.; Anal. Chim. Acta 2009, 653, 161; Zamani, 
H. A.; Arvinfar, A.; Rahimi, F.; Imani, A.; Ganjali, M. R.; Meghdadi, S.; Mater. Sci. Eng.: C 2011, 31, 307.

12. Calligaris, R. M. In Comprehensive Coordination Chemistry; Wilkinson, G.; Gillard, R. D., eds.; Oxford, 1987, p. 378.

13. Atwood, D. A.; Coord. Chem. Rev. 1997, 195, 267; Greenwood, N. N.; Earnshaw, A.; Chemistry of the Elements, Pergamon Press, 1984, p. 1430.

14. Shashikala D. K.; Ramaiah, M.; Vanital, J. K.; Veena, K.; Vaidya, V. P.; J. Chem. Pharm. Res. 2011, 3, 445.

15. Ganjali, M. R.; Rezapour, M.; Pourjavid, M. R.; Salavati-Niasari, M.; Poursaberi, T.; Anal. Lett. 2003, 36, 881; Ganjali, M. R.; Norouzi, P.; Daftari, A.; Faridbod, F.; Salavati-Niasari, M.; Sens. Actuators, B 2007, 120, 673 .

16. Djingova, R.; Ivanova, J.; Talanta 2002, 57, 821.

17. Kamata, S.; Bhale, A.; Fukunaga, Y.; Anal. Chem. 1988, 60, 2464.
18. Takeda, Y.; Bull. Chem. Soc. Jpn. 1983, 56, 3600.

19. Nicely, V. A.; Dye, J. I.; J. Chem. Educ. 1971, 48, 443.

20. IUPAC Analytical Chemistry Division, Commission on Analytical Nomenclature; Pure Appl. Chem. 1976, 48, 127.

21. Umezawa, Y.; Umezawa, K.; Sato, H.; Pure Appl. Chem. 1995, 67, 507.

22. Zamani, H. A.; Rajabzadeh, G.; Ganjali, M. R.; Talanta 2007, 72, 1093.

23. Pourjavid, M. R.; Norouzi, P.; Ganjali, M. R.; Int. J. Electrochem. Sci. 2009, 4, 923; Pourjavid, M. R.; Norouzi, P.; Ganjali, M. R.; Nemati, A.; Zamani, H. A.; Javaheri, M.; Int. J. Electrochem. Sci. 2009, 4, 1650; Pourjavid, M. R.; Norouzi, P.; Rashedi, H.; Ganjali, M. R.; J. Appl. Electrochem. 2010, 40, 1593.

24. Zamani, H. A.; Rajabzadeh, G.; Ganjali, M. R.; Norouzi, P.; Anal. Chim. Acta 2007, 598, 51

25. Marczenko, Z.; Separation and Spectrophotometric Determination of Elements, Elis Horwood Limited: Chichester, 1986. 